University of Montana

ScholarWorks at University of Montana

\title{
Nitrogen Spatial Heterogeneity Influences Diversity Following Restoration in a Ponderosa Pine Forest, Montana
}

\author{
Michael J. Gundale \\ Kerry L. Metlen \\ Carl E. Fiedler \\ University of Montana - Missoula, carl.fiedler@cfc.umt.edu \\ Thomas H. DeLuca
}

Follow this and additional works at: https://scholarworks.umt.edu/forest_pubs

Part of the Forest Management Commons

\section{Let us know how access to this document benefits you.}

\section{Recommended Citation}

Gundale, Michael J.; Metlen, Kerry L.; Fiedler, Carl E.; and DeLuca, Thomas H., "Nitrogen Spatial Heterogeneity Influences Diversity Following Restoration in a Ponderosa Pine Forest, Montana" (2006). Forest Management Faculty Publications. 14. https://scholarworks.umt.edu/forest_pubs/14

This Article is brought to you for free and open access by the Forest Management at ScholarWorks at University of Montana. It has been accepted for inclusion in Forest Management Faculty Publications by an authorized administrator of ScholarWorks at University of Montana. For more information, please contact scholarworks@mso.umt.edu. 


\title{
NITROGEN SPATIAL HETEROGENEITY INFLUENCES DIVERSITY FOLLOWING RESTORATION IN A PONDEROSA PINE FOREST, MONTANA
}

\author{
Michael J. Gundale, ${ }^{1,3}$ Kerry L. Metlen, ${ }^{2}$ Carl E. Fiedler, ${ }^{2}$ and Thomas H. Deluca ${ }^{1}$ \\ ${ }^{1}$ Department of Ecosystem and Conservation Sciences, University of Montana, Missoula, Montana 59812 USA \\ ${ }^{2}$ Department of Forest Management, University of Montana, Missoula, Montana 59812 USA
}

\begin{abstract}
The resource heterogeneity hypothesis (RHH) is frequently cited in the ecological literature as an important mechanism for maintaining species diversity. The RHH has rarely been evaluated in the context of restoration ecology in which a commonly cited goal is to restore diversity. In this study we focused on the spatial heterogeneity of total inorganic nitrogen (TIN) following restoration treatments in a ponderosa pine (Pinus ponderosa)/Douglas-fir (Pseudotsuga menziesii) forest in western Montana, USA. Our objective was to evaluate relationships between understory species richness and TIN heterogeneity following mechanical thinning (thin-only), prescribed burning (burn-only), and mechanical thinning with prescribed burning (thin/burn) to discern the ecological and management implications of these restoration approaches. We employed a randomized block design, with three 9-ha replicates of each treatment and an untreated control. Within each treatment, we randomly established a $20 \times 50 \mathrm{~m}\left(1000 \mathrm{~m}^{2}\right)$ plot in which we measured species richness across the entire plot and in $121-\mathrm{m}^{2}$ quadrats randomly placed within each larger plot. Additionally, we measured TIN from a grid consisting of 112 soil samples $(0-5 \mathrm{~cm})$ in each plot and computed standard deviations as a measure of heterogeneity. We found a correlation between the net increase in species richness and the TIN standard deviations one and two years following restoration treatments, supporting RHH. Using nonmetric multidimensional scaling ordination and chi-squared analysis, we found that high and low TIN quadrats contained different understory communities in 2003 and 2004, further supporting RHH. A comparison of restoration treatments demonstrated that thin/burn and burn-only treatments created higher $\mathrm{N}$ heterogeneity relative to the control. We also found that within prescribed burn treatments, TIN heterogeneity was positively correlated with finefuel consumption, a variable reflecting burn severity. These findings may lead to more informed restoration decisions that consider treatment effects on understory diversity in ponderosa pine/Douglas-fir ecosystems.
\end{abstract}

Key words: diversity; Douglas-fir; Lubrecht Experimental Forest; nitrogen; ponderosa pine; restoration treatments; richness; western Montana, USA.

\section{INTRODUCTION}

A central focus in ecology is to understand the underlying mechanisms that regulate and maintain patterns of diversity. Strong diversity patterns, such as an increase in species with area (Gleason 1922, MacArthur and Wilson 1967), a decrease in species with latitude (Pianka 1966), the regional hump-shaped relationship between productivity and diversity (Grime 1973, Rosenzweig and Abramsky 1993, Mittelbach et al. 2001 ), and the localized decrease in diversity with productivity following nutrient addition (Tilman 1982), have been thoroughly described. Ecologists have attempted to develop unifying theories that simultaneously explain these patterns. One such hypothesis, the resource heterogeneity hypothesis ( $\mathrm{RHH})$, suggests that diversity is a function of habitat or resource heterogeneity (Ricklefs 1977, Tilman 1984, Rozenzweig and

Manuscript received 17 March 2005; revised 6 June 2005; accepted 8 September 2005. Corresponding Editor: B. A. Hungate.

${ }^{3}$ E-mail: mjgundal@yahoo.com
Abramsky 1993, Tilman and Pacala 1993), which may promote species coexistence at multiple scales.

The basic premise of RHH is that species have sufficiently different niches from one another (MacArthur and Levins 1967) that each species is able to avoid displacement (Hardin 1960) under the unique set of resource conditions that complements its niche. A variety of resource conditions, therefore, promotes the coexistence of a variety of species, a concept referred to as beta diversity (Whittaker 1972). The fundamental prediction of RHH is that an area with heterogeneous resource availability will be more diverse than an equal area with homogeneous resource availability.

As with most hypotheses explaining diversity, RHH remains a viable one that is frequently referenced in the ecological literature and supported by some experimental evidence (Fitter 1982, Inouye and Tilman 1995, Burnett et al. 1997, Reynolds et al. 1997, Vivian-Smith 1997, Nichols et al. 1998, Sulkava and Huhta 1998). However, RHH has only rarely been considered in the applied field of restoration ecology, where a common 
goal of most restoration projects is to reestablish a diverse assemblage of native vegetation that has been diminished through some degradation process. An understanding of the manner in which restoration treatments create or diminish heterogeneity of limiting resources may help predict the potential for restoration to reestablish or maintain diversity. Furthermore, an understanding of how desirable native species and undesirable exotic species respond in different resource patches may allow land managers to better control the quality of diversity following restoration projects.

In the ponderosa pine ecosystems of the western U.S., fire exclusion over the last century has led to an increase in forest biomass, an increase in shade-tolerant species, and a loss of understory diversity (Arno 1980, Arno et al. 1995a, Fulé et al. 1997, Mast et al. 1999, Moore et al. 1999). It is likely that a corresponding change in nutrient availability, particularly $\mathrm{N}$, has occurred due to the immobilizing environment created by the accumulation of C-rich litter (Covington and Sackett 1984, Kaye and Hart 1998, MacKenzie et al. 2004). The frequent, lowintensity burning that reportedly dominated the disturbance regime prior to Euro-American settlement of the West likely created and maintained substantial heterogeneity of resources such as nitrogen. Furthermore, it is likely that the reduced $\mathrm{N}$ cycling believed to correspond with advancing secondary succession (MacKenzie et al. 2004) has led to greater spatial homogeneity of available $\mathrm{N}$, although these ideas remain untested.

Restoration is increasingly used in pine-dominated ecosystems to move stand structure toward historical conditions and reduce the risk of stand-replacing crown fires. Silvicultural methods, such as mechanical thinning, prescribed burning, and prescribed fire and mechanical thinning used together, are tools frequently used by land managers to accomplish these goals. While these treatments may effectively reduce fuel loadings and continuity (Pollet and Omi 2002, Fiedler et al. 2003), they may also influence $\mathbf{N}$ spatial heterogeneity and therefore lead to different levels of understory diversity.

The purpose of this study was to examine variability of $\mathrm{N}$ availability following four restoration alternatives in a ponderosa pine/Douglas-fir forest in western Montana, USA, and to determine whether this variation had any relationship to understory richness, a fundamental component of diversity. Furthermore, our objective was to identify species driving these diversity patterns. We focused on $\mathrm{N}$ because it has been cited as a limiting nutrient in this system (Vitousek and Howarth 1991, Mandzak and Moore 1994) and has been shown to respond rapidly to restoration treatments, whereas other soil nutrients appear less responsive (Covington and Sackett 1990, 1992, Monleon et al. 1997, DeLuca and Zouhar 2000, Gundale et al. 2005).

Our first hypothesis was that an underlying relationship between species richness and $\mathrm{N}$ heterogeneity would exist across all treatments, where plots with high $\mathrm{N}$ variability would contain a greater number of species than plots with low $\mathrm{N}$ heterogeneity. We also hypothesized that this diversity pattern at the plot level would be driven by divergence in species composition on highand low-N patches within the larger plots (beta diversity). We further hypothesized that species positively responding in high- $N$ patches would be fastgrowing colonizers, a number of which would be exotic species; by contrast, low-N patches would show a greater response by species with more conservative growth strategies. Last, we hypothesized that all treatments would show a higher degree of $\mathrm{N}$ heterogeneity than the untreated control, where we anticipated relatively low levels of $\mathrm{N}$ heterogeneity. Because harvesting activities often lead to clumped distributions of fuels, and fire is known to result in an accumulation of inorganic $\mathrm{N}$, we predicted that the greatest degree of $\mathrm{N}$ heterogeneity would be found in the restoration treatment that utilized both mechanical thinning and prescribed burning.

\section{Materials AND Methods}

Our study site is part of the Fire and Fire Surrogates (FFS) national study network, which includes 13 research sites utilizing similar experimental designs and sampling protocols. The FFS study is a multiyear interdisciplinary study investigating the effectiveness of cutting and burning treatments for reducing wildfire hazard. It is also examining treatment effects on vegetation, soils, insects, diseases, birds, and small mammals and wood utilization. Separate manuscripts from our study site describe treatment effects on soil physical, chemical, and biological properties (Gundale et al. 2005), understory vegetation (Metlen and Fiedler, in press), and invasive species (E. K. Dodson and C. E. Fiedler, unpublished manuscript).

We implemented our study in an approximately 100 year-old second-growth ponderosa pine/Douglas-fir forest at the University of Montana's Lubrecht Experimental Forest in western Montana, USA, at $47^{\circ} \mathrm{N}$ and $113^{\circ} \mathrm{W}$. Stands included in this study had not experienced fire in approximately 100 years. Mean annual air temperature is $7^{\circ} \mathrm{C}$, and mean annual precipitation is $50 \mathrm{~cm}$, with $44 \%$ falling as snow (Nimlos 1986). We used a blocked experimental design consisting of three 36-ha blocks. Soils in block one are clayeyskeletal, mixed Eutric Haplocryalfs. Soils within block two are loamy-skeletal, mixed, frigid Typic Dystrocryepts. Soils in block three are fine-silty, mixed Eutric Haplocryalfs. Blocks ranged in elevation from 1230 to $1388 \mathrm{~m}$. Each block was quartered into square 9-ha units and assigned one of four treatments (control, burn-only, thin-only, and thin/burn). We could not randomly assign one burn treatment in two of the blocks because positioning required consideration of preexisting firebreaks. All other treatments were randomly assigned. 


\section{Restoration treatments}

Restoration treatment prescriptions were designed to initiate the long-term transition toward historical ranges of stand density, structure, and species composition and to reduce hazard of stand-replacing wildfire. Restoration targets for these stand characteristics were based on early stand descriptions (Anderson 1933), studies of relict old-growth ponderosa pine stands in Montana (Arno et al. 1995b, Fiedler 2000), and ongoing unevenaged silvicultural research (Fiedler 1995, 1999).

Pretreatment basal area densities ranged from 20.6 to $23.8 \mathrm{~m}^{2} / \mathrm{ha}$ (trees $>10 \mathrm{~cm}$ diameter) among the four treatments. The basal area of pretreatment stands was composed of approximately $60 \%$ ponderosa pine and $40 \%$ Douglas-fir, with individual tree diameters ranging from 10 to $70 \mathrm{~cm}$.

The restoration cutting prescription set a posttreatment basal area target of $11 \mathrm{~m}^{2} / \mathrm{ha}$ (trees $>10 \mathrm{~cm}$ diameter), with a long-term goal of one-half to twothirds of the basal area in trees $\geq 50 \mathrm{~cm}$ diameter. The long-term species composition target is $\geq 90 \%$ ponderosa pine. Restoration cutting was conducted in the winter of 2000-2001 on frozen, snow-covered soil. A cut-to-length harvest system was used to cut and limb trees in the woods. Logging slash (tops and limbs) and nonmerchantable materials were left on-site to serve as a buffer between logging equipment and the soil. A lowimpact log forwarder transported merchantable timber to a landing area outside each treatment unit.

The goal of prescribed burning was to reduce fuel loads and to move existing stand structure and species composition toward historical conditions. The six units assigned the burn treatment received separate prescribed broadcast burns in the spring of 2002. All burns were conducted using the same procedures, but variation in weather conditions among burn days and in the volume and distribution of fuels within each treatment unit led to variation in fire behavior and effects.

\section{Field methods}

Within each 9-ha unit, a $6 \times 6$ grid was established, yielding 36 permanent reference points. One reference point within each replicate was randomly chosen to serve as a center point for a $1000 \mathrm{~m}^{2}$ plot $(20 \times 50 \mathrm{~m})$. This yielded a total of three $1000-\mathrm{m}^{2}$ plots per treatment. Within each plot, soil samples were collected in a grid pattern consisting of 16 rows and seven columns, with each point separated from its nearest neighbor by $3 \mathrm{~m}$ (Fig. 1).

We collected mineral soil samples $(0-5 \mathrm{~cm})$ at each grid location in June and July 2002 and again in 2003, using a standard $2.5-\mathrm{cm}$ soil probe. All treatments within a block were sampled before initiating sampling in the next block. This allowed us to evenly distribute any temporal variation across all treatments. Soil samples were transported and stored under refrigeration and extracted the following day. Extractable $\mathrm{NH}_{4}{ }^{+}$and $\mathrm{NO}_{3}{ }^{-}$were extracted by shaking $25 \mathrm{~g}$ (dry mass

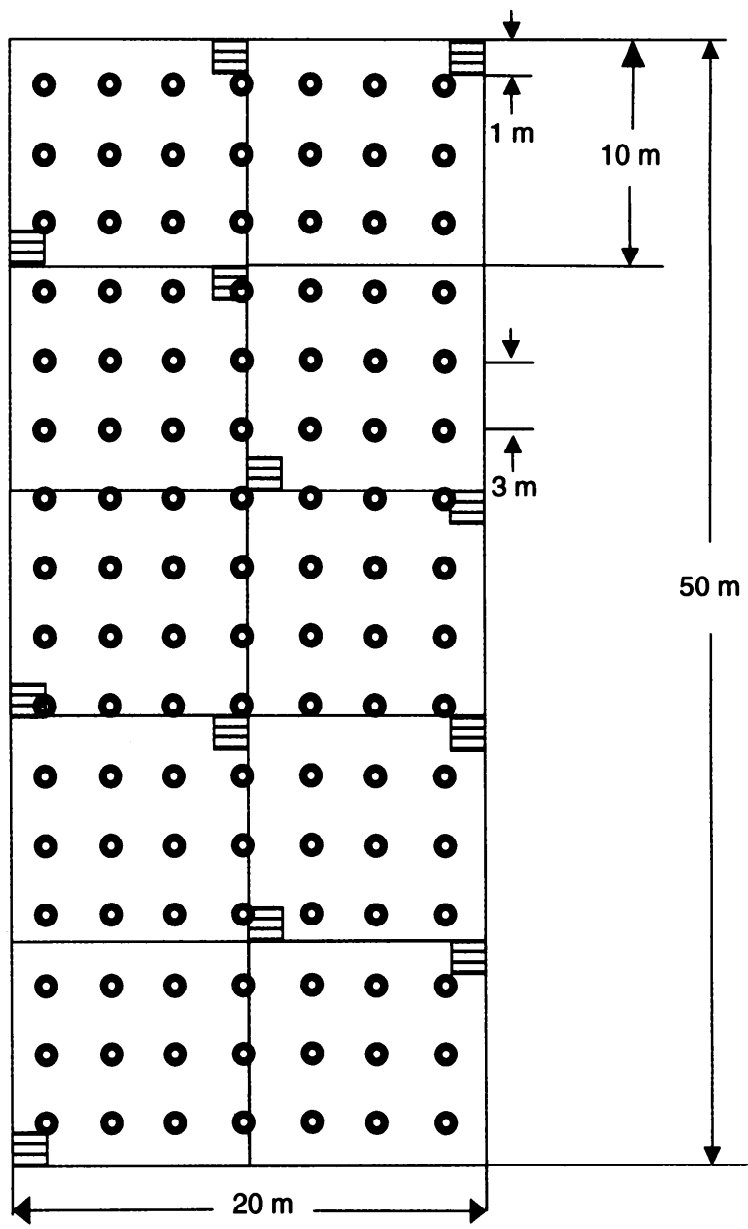

FIG. 1. Sampling design for vegetation and soil nitrogen. Species diversity (presence/absence) was sampled at the 1000$\mathrm{m}^{2}$ plot level and in $121-\mathrm{m}^{2}$ quadrats within each plot. Soil samples $(0-5 \mathrm{~cm})$ were collected from a grid of 112 sample points (open circles) within each plot.

equivalent) of soil in $50 \mathrm{~mL}$ of $2 \mathrm{~mol} / \mathrm{L} \mathrm{KCL}$ followed by filtration through Whatman number $42(2.5-\mu \mathrm{m})$ filter paper. Extracts were analyzed on a segmented flow autoanalyzer using the Berthelot reaction (Willis et al. 1993) and cadmium reduction method (Willis and Gentry 1987), respectively. Hereafter we report $\mathbf{N}$ as total inorganic nitrogen (TIN), which consists of the combined concentrations of $\mathrm{NH}_{4}^{+}$and $\mathrm{NO}_{3}{ }^{-}$. We combined these pools because $\mathrm{NH}_{4}{ }^{+}$and $\mathrm{NO}_{3}{ }^{-}$individually demonstrated noticeable temporal variation during the sampling period, whereas TIN appeared to have greater stability.

We used richness of understory vascular plants as a measure of diversity. We sampled species richness at two spatial scales: $1000-\mathrm{m}^{2}$ plots $(20 \times 50 \mathrm{~m})$ and $121-\mathrm{m}^{2}$ quadrats $(1 \times 1 \mathrm{~m})$ within each $1000-\mathrm{m}^{2}$ plot (Fig. 1). A modified random process was used to disperse quadrats throughout each $1000-\mathrm{m}^{2}$ plot. The $1000-\mathrm{m}^{2}$ plots were first subdivided into $1010-\mathrm{m}^{2}$ subplots $(10 \times 10 \mathrm{~m})$ 
Quadrats were then randomly placed in one or two opposing corners of each $100-\mathrm{m}^{2}$ subplot, with at least one but no more than two quadrats per subplot. We conducted pretreatment vegetation sampling in the summers of 2000 and 2001 and posttreatment sampling in the summers of 2003 and 2004. We report richness as delta species richness, which is the net difference in richness between pretreatment and posttreatment measurements. This measure standardized the richness response among plots, where preexisting variation in richness occurred. Species were identified to the lowest taxonomic level possible using the taxonomy key of Hitchcock and Cronquist (1973). Species were identified as native or exotic using Hitchcock and Cronquist (1973) and the USDA Plants Database (version 3.5, available online) ${ }^{4}$

We estimated surface fuels in all units before and after treatment implementation by randomly placing two $15.2 \mathrm{~m}$ long transects at the 36 permanent sampling points in each treatment unit. Fuel loads $(<7.6 \mathrm{~cm})$ along each transect were estimated following the protocol of Brown et al. (1982). We defined fine fuels as consisting of 100 -h fuels $(2.5-7.6 \mathrm{~cm}), 10$-h fuels $(0.6-$ $2.5 \mathrm{~cm}), 1$-h fuels $(0-2.5 \mathrm{~cm})$, and litter (Oi). Gundale et al. (2005) provides a more complete description of fuel quantities and consumption in each treatment.

\section{Statistical analysis}

We tested our first hypothesis by computing Pearson's correlation coefficients between total inorganic nitrogen (TIN) standard deviations and delta species richness, using all $121000-\mathrm{m}^{2}$ plots (three per treatment). Total inorganic nitrogen standard deviations were computed for each $1000-\mathrm{m}^{2}$ plot using the 112 values of inorganic $\mathrm{N}$ collected within each plot's sample grid. Delta species richness was the change in richness in each $1000-\mathrm{m}^{2}$ plot from pretreatment to posttreatment sampling time (2003 and 2004). These analyses were performed using SPSS version 12.0 software (SPSS, Chicago, Illinois, USA).

We tested our second hypothesis, that species diverged on low- and high-N quadrats, through nonmetric multidimensional scaling (NMS) (Kruskal 1964, Mather 1976) using PC-ORD software (MjM Software Design, Gleneden Beach, Oregon, USA). We constructed the model using species cover values in all quadrats $(n=$ 144). The model included species composition of these quadrats $(81,106$, and 118 species in pretreatment, 2003, and 2004, respectively) across all years (2000, 2003, and 2004) so that we could evaluate whether species composition in high- and low-TIN quadrats diverged through time following restoration. Quadrat TIN concentrations were estimated from their closest gridpoint $(<1 \mathrm{~m})$. We defined quadrats with high and low TIN as falling above or below the median TIN concentration of all 144 quadrats sampled. Both highand low-TIN quadrats were distributed among all

\footnotetext{
${ }^{4}\langle$ http://plants.usda.gov $\rangle$
}

TABLE 1. The distribution of high and low total inorganic nitrogen quadrats among treatments during 2002 and 2003.

\begin{tabular}{llcccc}
\hline \hline Year & N group & Control & Thin-only & Burn-only & Thin/burn \\
\hline 2002 & High N & 20 & 7 & 17 & 28 \\
& Low N & 16 & 29 & 19 & 8 \\
2003 & High N & 16 & 16 & 18 & 22 \\
& Low N & 20 & 20 & 18 & 14 \\
\hline
\end{tabular}

Note: Each high- and low-N group consisted of 72 quadrats.

treatments in 2002 and 2003 (Table 1). Species cover values were adjusted by subtracting the block median cover value for each species to minimize block effects before analysis (B. McCune, personal communication). We used Euclidean distance to accommodate negative values created during this blocking procedure. The ordination satisfied three criteria that indicated it satisfactorily represented the data in original multidimensional space (McCune and Grace 2002). First, the cumulative coefficient of determination indicated that the model represented a large portion of the variation in the original data set $\left(r^{2}=0.80\right)$. Second, the ordination had an acceptable level of stress $(S=17.46)$, indicating a minimal loss of separation between plots in ordination space relative to the original multidimensional space (McCune and Grace 2002). Lastly, Monte Carlo tests ( $n$ $=50$ ) determined that there was a low probability that the final stress values occurred by chance $(p=0.02)$ and thus suggested the final ordination was stable (instability $=0.00048$ ). The final solution was rotated to maximize the correlation of axis 1 with TIN (2002). We used multiple response permutation procedures (PC-ORD software, MjM Software Design) to determine whether high- and low- $\mathrm{N}$ quadrats differed in this ordination space (three axes).

To test our third hypothesis, we used chi-square tests (Zar 1999) to identify species whose frequency increased between pretreatment and posttreatment sampling periods. The chi-square test was chosen because it allowed us to directly identify species positively responding in high- and low-TIN quadrats. We conducted analyses for all four groupings of quadrats: low N 2002, low N 2003, high N 2002, and high N 2003. These analyses utilized $2 \times 2$ contingency tables $(\mathrm{df}=1, \alpha=$ 0.05 ) with pretreatment and posttreatment columns, and rows consisting of presence and absence counts for each column. Species too rare to satisfy the requirement that each expected cell frequency be at least five (Zar 1999) were removed from the analysis. Any species whose frequency significantly increased in both high- and low$\mathrm{N}$ quadrats during a given posttreatment year were also removed. Thus, we report only species positively increasing within high- or low-N quadrats (Table 2).

Both the NMS ordinations and chi-square analyses were based on 144 quadrats, 12 within each $1000-\mathrm{m}^{2}$ plot. These quadrats may exhibit some degree of spatial autocorrelation, meaning quadrats within $1000-\mathrm{m}^{2}$ plots are more similar to one another than to quadrats in 
TABLE 2. Species that increased in frequency in high or low total inorganic nitrogen (TIN) quadrats compared to pretreatment levels.

\begin{tabular}{|c|c|c|c|c|c|c|}
\hline Nitrogen group/year & Species & $\chi^{2}$ & $P$ & Origin & Longevity & Life form \\
\hline \multicolumn{7}{|l|}{2003 vegetation } \\
\hline High/2002 & $\begin{array}{l}\text { Chamerion angustifolium } \\
\text { Verbascum thapsus } \\
\text { Carex geyeri } \\
\text { Collomia linearis }\end{array}$ & $\begin{array}{l}7.4 \\
7.4 \\
6.3 \\
5.2\end{array}$ & $\begin{array}{l}* * \\
* * \\
* \\
*\end{array}$ & $\begin{array}{l}\text { native } \\
\text { exotic } \\
\text { native } \\
\text { native }\end{array}$ & $\begin{array}{l}\text { perennial } \\
\text { biennial } \\
\text { perennial } \\
\text { annual }\end{array}$ & $\begin{array}{l}\text { forb } \\
\text { forb } \\
\text { graminoid } \\
\text { forb }\end{array}$ \\
\hline Low/2002 & Carex concinnoides & 6.1 & * & native & perennial & graminoid \\
\hline \multicolumn{7}{|l|}{2004 vegetation } \\
\hline High/2003 & $\begin{array}{l}\text { Cirsium vulgare } \\
\text { Collomia linearis } \\
\text { Logfia arvensis } \\
\text { Verbascum thapsus } \\
\text { Taraxacum officinale } \\
\text { Penstemon spp. } \dagger\end{array}$ & $\begin{array}{r}11.9 \\
7.4 \\
7.4 \\
7.4 \\
4.2 \\
4.0\end{array}$ & $\begin{array}{c}* * * \\
* * \\
* * \\
* * \\
* \\
*\end{array}$ & $\begin{array}{l}\text { exotic } \\
\text { native } \\
\text { exotic } \\
\text { exotic } \\
\text { exotic } \\
\text { native }\end{array}$ & $\begin{array}{l}\text { biennial } \\
\text { annual } \\
\text { annual } \\
\text { biennial } \\
\text { perennial } \\
\text { perennial }\end{array}$ & $\begin{array}{l}\text { forb } \\
\text { forb } \\
\text { forb } \\
\text { forb } \\
\text { forb } \\
\text { forb }\end{array}$ \\
\hline Low/2003 & $\begin{array}{l}\text { Erythronium grandiflorum } \\
\text { Viola adunca } \\
\text { Lomatium triternatum } \\
\text { Poa secunda }\end{array}$ & $\begin{array}{l}3.9 \\
3.9 \\
3.8 \\
3.8\end{array}$ & $\begin{array}{l}* \\
* \\
* \\
*\end{array}$ & $\begin{array}{l}\text { native } \\
\text { native } \\
\text { native } \\
\text { native }\end{array}$ & $\begin{array}{l}\text { perennial } \\
\text { perennial } \\
\text { perennial } \\
\text { perennial }\end{array}$ & $\begin{array}{l}\text { forb } \\
\text { forb } \\
\text { forb } \\
\text { forb }\end{array}$ \\
\hline
\end{tabular}

Note: High and low quadrats were identified as above or below the median TIN for 2002 or 2003.

${ }^{*} P<0.05 ;{ }^{* *} P<0.01 ;{ }^{* * *} P<0.001$.

$\dagger$ Penstemon spp. include $P$. procerus, $P$. confertus, and their hybrids.

other $1000-\mathrm{m}^{2}$ plots. Despite the possible presence of spatial autocorrelation, these analyses are appropriate because they are secondary analyses to investigate the mechanisms driving the observed positive relationship between species richness and $\mathrm{N}$ heterogeneity. The potential influence of spatial autocorrelation suggests caution in extrapolating the identified response of individual species beyond our study.

We tested our fourth hypothesis by determining whether TIN standard deviation differed among restoration treatments using analysis of variance, followed by the Student-Newman-Keuls post hoc procedure. Distributional assumptions were graphically assessed and heteroscedasticity was tested using Levene's statistic. Finally, as an ad hoc analysis, we tested whether a relationship existed between TIN standard deviation and fine fuels consumed by computing correlation coefficients for data from the six $1000-\mathrm{m}^{2}$ plots treated with prescribed fire. These analyses were done using SPSS version 12.0 software.

\section{Results AND Discussion}

\section{Nitrogen heterogeneity and understory species diversity}

Forest restoration treatments induced a notable increase in $\mathrm{N}$ heterogeneity that appears to be closely correlated with species diversity throughout the study area. Evidence for this relationship was provided at the $1000-\mathrm{m}^{2}$ plot level, where the data showed a positive relationship $(r=0.63 ; P<0.05)$ between delta species richness in 2003 and TIN heterogeneity in 2002 (Fig. 2a), indicating that plots with the greatest TIN heterogeneity resulted in the largest net increase in species the following year. This relationship weakened $(r=0.51 ; P$ $<0.10$ ), but remained positive one year later, when delta species richness in 2004 was correlated with TIN heterogeneity 2003 (Fig. 2b). The weaker relationship found during the second sampling period (Fig. 2b) was primarily due to a single outlier. This plot was located under an unusually dense patch of overstory that experienced little mortality during the prescribed fire. Therefore, understory diversity may have been decoupled from TIN heterogeneity in this plot due to exceptional overstory competition before and after restoration treatment. In the absence of this outlier, the relationship between TIN heterogeneity and diversity remained strong ( $r=0.68, P<0.05$; Fig. $2 b$ ).

Interestingly, delta species richness in 2002 was not significantly correlated with TIN standard deviations during 2002 (data not shown), whereas delta species richness in 2003 showed a significant positive relationship with TIN standard deviations during 2002 (Fig. 2a). Likewise, TIN standard deviation in 2003 was more strongly correlated with delta species richness in 2004 than during the same year. These results suggest that overall delta richness at the $1000-\mathrm{m}^{2}$ level lags behind TIN heterogeneity. The time required for plants to respond to changing resource availability likely accounts for some of this observed lag.

\section{Patch-level community divergence}

A factor potentially confounding the interpretation of these correlations (Fig. 2) is the co-varying relationship between TIN heterogeneity and mean TIN within a plot. In other words, plots with higher TIN standard deviations also had higher TIN means (SD vs. mean, 2002, $\left.r^{2}=0.82, P<0.05 ; 2003, r^{2}=0.66, P<0.05\right)$. Richness, therefore, could increase through two mechanisms: an increase in resources (which likely equates to higher productivity) or a more diverse set of resource conditions (heterogeneity). These two factors cannot be 

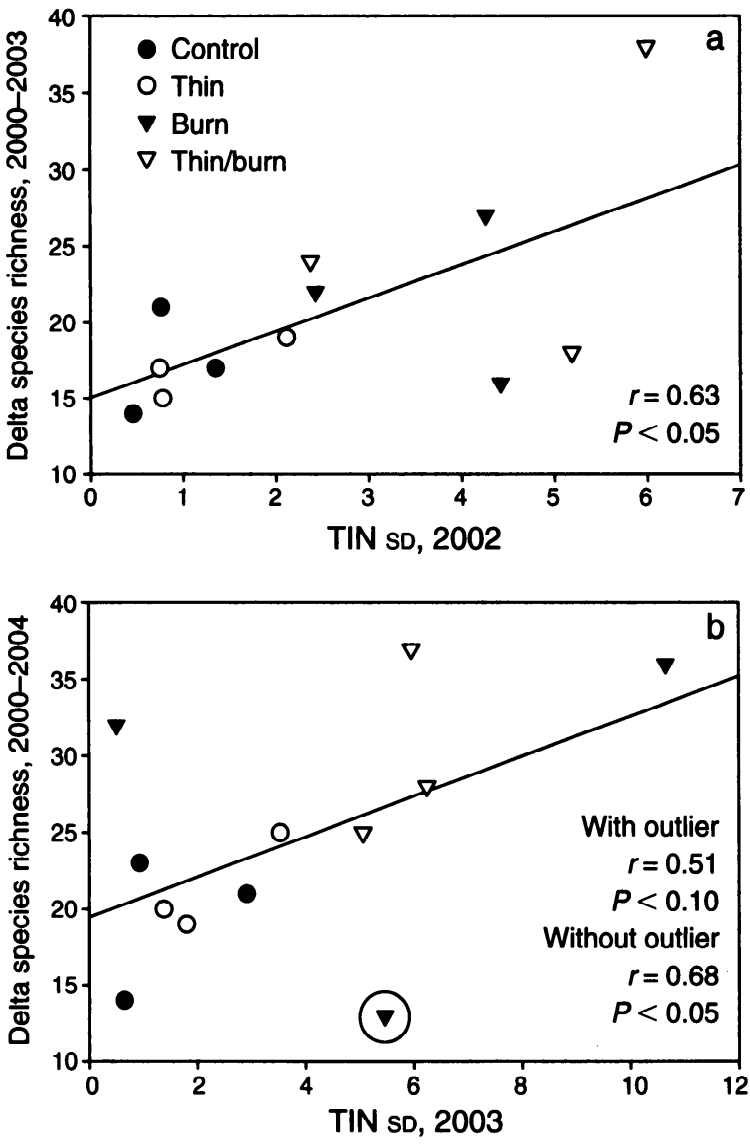

FIG. 2. The correlation between delta species richness in (a) 2003 and (b) 2004 and plot total inorganic nitrogen (TIN) standard deviation in 2002 and 2003, respectively. The circled point in 2004 is an outlier.

fully separated in our data set because we did not observe any plots with high means and small standard deviations or plots with small means and large standard deviations. We did, however, find some supporting evidence that TIN heterogeneity contributed to plotlevel species richness by comparing species composition on high and low quadrats within the plots, using an NMS ordination model of all quadrats across all years. This analysis indicated no preexisting differences in species composition between high- and low- $\mathrm{N}$ quadrats (2002) prior to restoration (Fig. 3). Following restoration treatments, high- and low-TIN quadrats moved farther apart in ordination space (2003, $A=0.005, P=$ $0.07 ; 2004, A=0.011, P=0.02 ; A$ is the multiple response permutation procedures [MRPP] test statistic), indicating increasing divergence in species composition between these groups of quadrats.

These data (Figs. 2 and 3) provide support for RHH. Heterogeneity of limiting soil resources is frequently cited in the literature as a mechanism maintaining plant diversity in many systems (Ricklefs 1977, Tilman 1984, Rosenzweig and Abramsky 1993, Tilman and Pacala 1993); however, far fewer studies have provided evidence that such a relationship actually exists. The large sampling effort required to adequately measure spatial variation of soil resources likely limits investigation of this hypothesis. Our data are consistent with several studies, however, that provide support for RHH by showing that species composition was dissimilar on different resource patches (Fitter 1982, Inouye and Tilman 1995, Burnett et al. 1997, Reynolds et al. 1997, Vivian-Smith 1997, Nichols et al. 1998, Sulkava and Huhta 1998). Other studies have demonstrated that small-scale heterogeneity of geomorphological characteristics, known to strongly influence resource availability, is strongly correlated with diversity at a larger scale (Burnett et al. 1997, Vivian-Smith 1997, Nichols et al. 1998).

To our knowledge, only one previous study has investigated the influence of $\mathrm{N}$ heterogeneity on diversity in the context of restoration. In a Kansas grassland, Baer et al. (2004) manipulated soil $N$ concentrations prior to restoration and measured species diversity following restoration. Unlike our study, they found that heterogeneous $\mathbf{N}$ plots did not result in an increase in species relative to homogeneous plots shortly following restoration. There are several potential explanations for these disparate results. Baer et al. (2004) noted that lack of response to $\mathrm{N}$ heterogeneity in their study may have been due to the dominance of a native grass in all plots. We had no such dominant species in our study. Additionally, our spatial scale was much greater than that used by Baer et al. (2004), which likely incorporated the response of a larger number of species and minimized the influence of individual species. These disparate results may also reflect more severe $\mathrm{N}$ limitation in ponderosa pine/Douglas-fir forests compared to disturbed grassland. We are unaware of any additional published analyses of diversity and soil resource heterogeneity relationships in the context of forest restoration.

Our data provide support that increasing $\mathrm{N}$ heterogeneity corresponds with increasing plant diversity. We focused on TIN because of its likely limitation to plant growth in this system and its rapid increase following disturbance. Further, belowground competition has been documented as an important structuring component of the understory community in the ponderosa pine ecosystem (Riegel et al. 1992, 1995). We acknowledge that resource limitations other than $\mathrm{N}$ likely exist and may exhibit spatial heterogeneity, such as light and water, both of which are likely altered by restoration treatments and may exhibit spatial heterogeneity. Additionally, some variation in species richness is likely a function of the stochastic nature of dispersal, where individual plots or quadrats may differ because of differences in seed banks and propagule pressure. Factors such as these may account for a large portion of the unexplained variation in our data. It is also unclear whether the relationships described here extend throughout the ponderosa pine ecosystem. Abiotic stress 


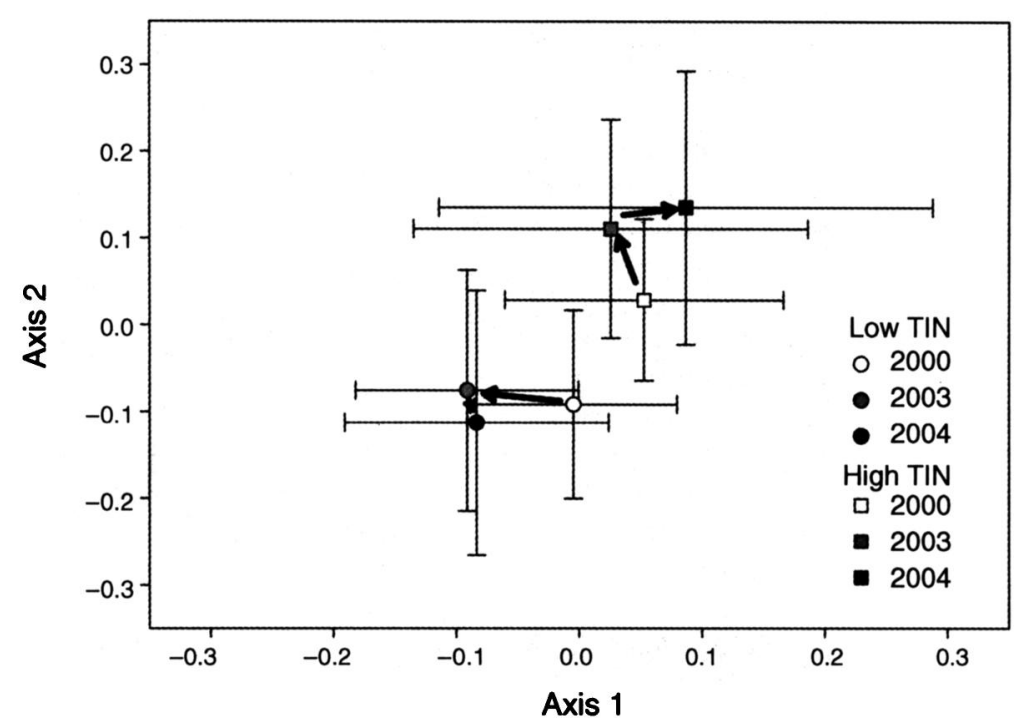

FIG. 3. A nonmetric multidimensional scaling ordination of vegetation quadrats $(n=144)$ during three sampling years $(2000$, 2003 , and 2004). Understory species composition of quadrats with low and high total inorganic nitrogen (TIN) in $2002( \pm 95 \% \mathrm{Cl})$ did not significantly differ in 2000 (pre-treatment), was marginally different in $2003(A=0.005, P=0.07)$, and was more highly significant in $2004(A=0.011, P=0.02)$. $A$ is the multiple response permutation procedures (MRPP) test statistic. Axes 1 and 2 explained $31 \%$ and $20 \%\left(r^{2}=0.31, r^{2}=0.20\right)$ of the variation in the original data set, respectively.

or limitation of other resources may organize the understory community to a greater degree at other sites or in other regions.

\section{Species attributes and exotic species}

We identified numerous species whose frequency significantly increased in high- or low-N quadrats. In high- $N$ quadrats, four species in 2003 and six species in 2004 were significantly more frequent relative to pretreatment (Table 2). Species that demonstrate an increased frequency in high- $\mathrm{N}$ patches were primarily forbs with high growth rates and excellent dispersal abilities, attributes that allow these species to respond quickly to resource pulses. Chamerion angustifolium, Collomia linearis, Cirsium vulgare, Taraxacum officinale, and Logfia arvensis are prolific producers of winddispersed seeds that are known to establish well after disturbance (Stickney and Campbell 2000). All but two of these species have annual or biennial growth habits. Another species associated with high-N plots, Verbascum thapsus, has long-lived seeds that remain dormant in the seed bank until disturbance events create favorable conditions for germination (Burnside et al. 1996).

In low-N quadrats, only one species in 2003 and four species in 2004 were significantly more frequent relative to pretreatment (Table 2). All species in low-N quadrats (Table 2) were native perennials, and all but one have underground storage structures, including corms, bulbs, or rhizomes. These structures likely facilitate nutrient retention and allow associated species to persist in lowresource conditions. Their increased frequency likely does not reflect a response to low $\mathrm{N}$ per se, but rather a response to disturbance on sites where resources other than $\mathbf{N}$ were substantially altered, such as light availability.

An increase in diversity is generally considered desirable; however, our data suggest that high-N patches are also more likely to be colonized by exotic species (Table 2). One of four species in 2003 and four of six species in 2004 that positively responded to high-N quadrats are considered exotic in western coniferous forests. In contrast, no exotic species were associated with low-N quadrats (Table 2). While not all exotic species are necessarily invasive, $V$. thapsus and $C$. vulgare have characteristics of invasive species (Gross and Werner 1982, Petryna et al. 2002). These results are consistent with Baer et al. (2004), who found a greater number of exotic species in high- $\mathrm{N}$ plots following grassland restoration.

Invasive species in many systems have been shown to have common physiological and morphological traits. One such characteristic is a higher specific leaf area relative to native vegetation (Baruch and Goldstein 1999, Smith and Knapp 2001), which closely corresponds with a high relative growth rate and a high- $\mathrm{N}$ requirement (Lambers and Poorter 1992, Reich et al. 1997). Additionally, these species tend to have exceptional seed production and dispersal abilities (Stickney and Campbell 2000). Thus, it may be difficult in most restoration operations to promote native species richness without also providing opportunities for exotic species colonization. Despite initial colonization of exotics, their invasion may be limited in duration. The exotic species identified in this study have been shown to require continued disturbance in order to persist in forest environments (Gross and Werner 1982, Petryna et al. 2002). Further 
study is needed of the persistence and impacts of these exotic species following restoration treatments.

Both high- and low-N quadrats were distributed among all restoration treatments during 2003 and 2004 (Table 1), suggesting that increased frequency of these species is not necessarily a function of a single restoration treatment. High-N quadrats likely exist for a variety of reasons across all treatments. A majority of high-N quadrats occurred in the burn-only and thin/burn treatments, likely due to fuel consumption from burning that resulted in high levels of $\mathrm{NH}_{4}{ }^{+}$accumulation. A surprisingly large number of high-N quadrats also occurred in the thin-only and control, which may have resulted from soil disturbance or their location on moist microsites. Low-N quadrats existed in all treatments and thus also likely reflect varying degrees of disturbance. In addition to undisturbed quadrats in the control, low-N quadrats likely occurred on unburned or low-severity burn patches in the burn treatments and in locations experiencing a range of disturbance severity in the thin-only treatment.

The analysis we used to determine which species responded in high- or low-N quadrats was based on a small area $\left(144 \mathrm{~m}^{2}\right)$; thus, we likely identified only a portion of the species in this system that responded in high- or low-N patches. The identified species, however, exhibit several attributes that are likely to be advantageous in low- or high-N environments. It is recognized that the traits of successful competitors in nutrient-rich and nutrient-poor locations differ substantially (Aerts 1999). Low-resource environments may favor species with characteristics that promote nutrient retention. These include features such as long leaf life span and increased production of secondary metabolites within leaves, which in turn result in slow $\mathbf{N}$ mineralization when litter is deposited on the forest floor (Aerts 1997). Aerts (1999) suggested that species with nutrient retention characteristics create soil-plant feedbacks, where low nutrient mineralization from their own litter leads to self-dominance. Under these low-resource conditions, high $\mathrm{N}$-demanding species perform poorly because the nutrient supply is too limited to sustain their high growth rates. The very characteristics that allow low-N species to be successful competitors in low-N sites make them poor competitors in high-nutrient environments because they lack the rapid growth rates needed to quickly acquire resources and avoid shading by competitors. The species we found associated with highand low- $\mathrm{N}$ quadrats appear to reflect this trade-off.

\section{Heterogeneity differences among treatments}

Because an underlying relationship between TIN heterogeneity and species diversity has been identified, a pertinent question is which restoration treatment generates the highest degree of TIN heterogeneity and thus is likely to result in higher diversity. A comparison of TIN standard deviation among treatments showed that both burn treatments became more heterogeneous $(\mathrm{df}=11,2$, $F=6.977, P=0.013$ ) relative to the control in 2002 (Fig.
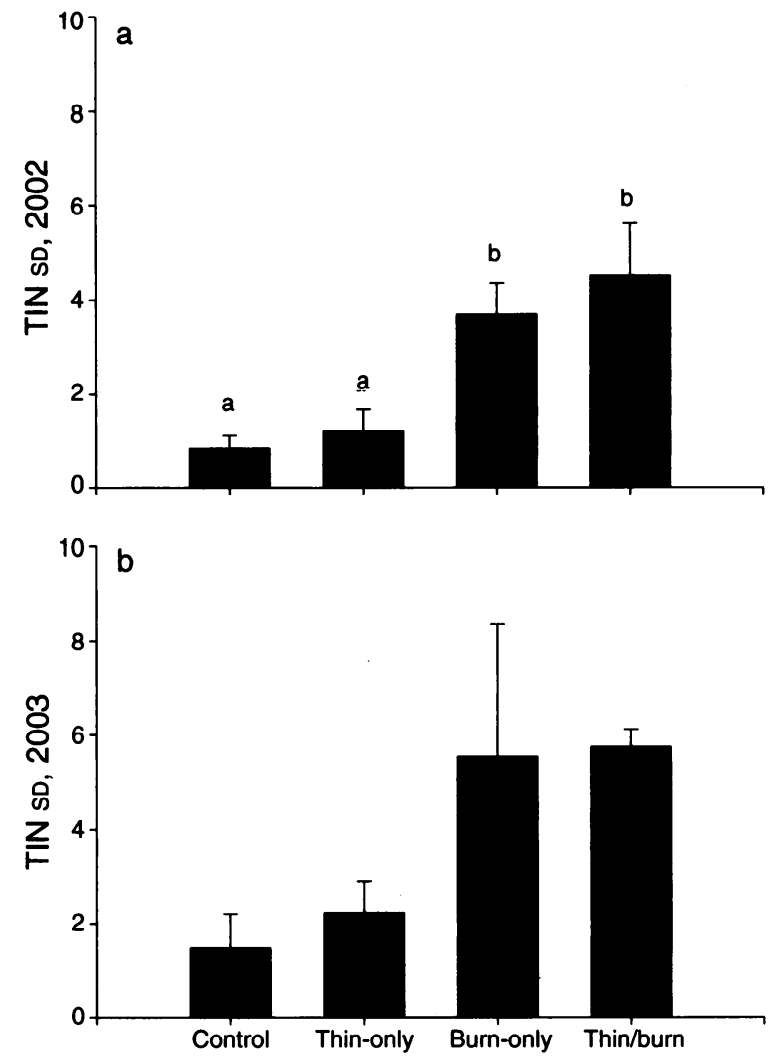

FIG. 4. Standard deviations (mean $+\mathrm{SE}$ ) of total inorganic nitrogen (TIN) following four restoration treatments (control, thin-only, burn-only, and thin/burn). Letters above bars indicate post hoc differences between treatments.

4a). In 2003, differences became slightly nonsignificant ( $\mathrm{df}=11, F=2.019, P=0.190$ ), primarily due to the large standard error in the second replicate of the burn-only treatment (Fig. 4b). This large standard error resulted from a dramatic increase in TIN heterogeneity in a single burn-only plot from 2002 to 2003 . Unlike any other plot included in the analysis, this plot was heavily colonized by the liverwort Marchantia polymorpha. There is some evidence that members of the genus Marchantia associate with $\mathrm{N}$-fixing bacteria (Brassell et al. 1986), thus this plot may have had an unusually large $\mathrm{N}$ input that resulted in increased heterogeneity. These treatment differences in $\mathbf{N}$ spatial heterogeneity corresponded with treatment level ( 9 ha) differences in diversity (Metlen and Fiedler, in press) and exotic species colonization (Dodson 2004). Thus, it is plausible that $\mathbf{N}$ heterogeneity contributes to the overall diversity and exotic species response at the treatment level; however, we have no measurement of this heterogeneity/diversity relationship at this larger scale to directly support this.

It has been suggested that fire historically maintained spatial heterogeneity of resources in many systems (Raison 1979) and that exclusion of fire has led to a decrease in heterogeneity (Bonnicksen and Stone 1982). Reduced $\mathrm{N}$ heterogeneity may occur over time through 
a variety of processes, including selective root foraging in high resource patches, gradual invasion and densification of trees in forest openings, mass flow and leaching, and an increase in C-rich substrates that lead to increased $\mathrm{N}$ immobilization throughout the stand. The control in our study is representative of ponderosa pine/Douglas-fir forests in western Montana lacking wildfire for nearly a century. It is impossible to know what $\mathbf{N}$ spatial patterns existed prior to fire exclusion, which precludes us from evaluating our data in terms of reference conditions. However, the data clearly show that stands in later stages of secondary succession have a low degree of $\mathbf{N}$ spatial heterogeneity as a result of fire exclusion (Fig. 4). The data also provide evidence that the reintroduction of fire through prescribed burning increases heterogeneity of available $\mathbf{N}$.

We also found that within the first year of prescribed burning, $\mathbf{N}$ heterogeneity was positively correlated with fine-fuel consumption (Fig. 5), a variable that is a proxy for fire severity. Fuel consumption during prescribed burning is a function of the abundance and distribution of fuels and weather conditions during burn days. These data imply that the addition of fuels to the forest floor through thinning operations or variation in weather conditions during burn days can influence spatial heterogeneity of $\mathbf{N}$ and thus indirectly influence species richness. An important objective for future research is to determine the manner in which $\mathrm{N}$ heterogeneity responds across a greater range of fire severities. It is plausible that $\mathrm{N}$ heterogeneity would demonstrate a unimodal relationship with fire severity. Severe fire may create spatial homogeneity that in turn leads to low diversity.

\section{Conclusions}

Results of this study suggest that an underlying relationship exists between TIN heterogeneity and understory plant species diversity in ponderosa pine/ Douglas-fir forests and thus also provide support for RHH. This relationship appeared to be driven, in part, by divergence of species composition on high- and low $\mathrm{N}$ patches. Species growing in high-TIN quadrats were generally faster growing annuals and biennials, many of which were exotic. Species that responded in low-N quadrats were all native and were generally slower growing perennials with some underground storage structure.

Our data also indicate that the untreated control, which has not experienced fire for over a century, exhibits a low degree of TIN heterogeneity. Additionally, both prescribed burn treatments resulted in higher levels of TIN heterogeneity relative to the control, whereas the thin-only treatment did not result in increased heterogeneity relative to the control. These data suggest that the restoration treatments land managers choose to restore fire-excluded ponderosa pine forests can directly influence $\mathrm{N}$ heterogeneity and subsequently influence species diversity as well. It is

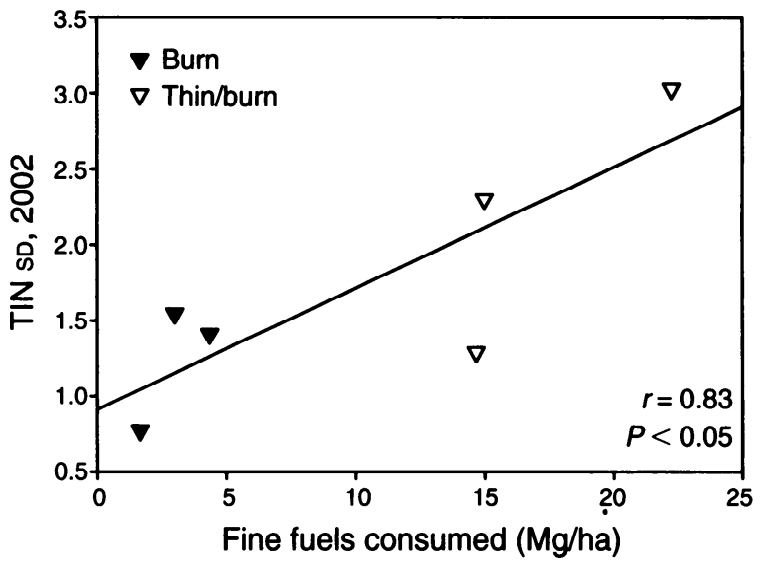

FIG. 5. The correlation between standard deviation of total inorganic nitrogen (TIN) in 2002 and fine fuels consumed during prescribed burning of six 9-ha units.

unclear whether TIN heterogeneity produced by restoration treatments is representative of historical conditions. Presumably, the frequent low-intensity fires that historically dominated western Montana ponderosa pine forests created and maintained heterogeneity; however, it may be impossible to reconstruct this aspect of reference conditions. These findings demonstrate the influence that $\mathrm{N}$ heterogeneity has on diversity in the context of ponderosa pine/Douglas-fir forest restoration and may lead to more informed restoration decisions that consider treatment effects on understory diversity.

\section{ACKNOWLEDGMENTS}

This research is contribution 83 of the National Fire Surrogates Project (FFS), funded by the U.S. Joint Fire Science Program. We would like to acknowledge the input from $\mathrm{J}$. Graham and the field and lab assistance of F. Farrell, T. Brown, T. Ream, K. Gundale, and E. K. Dodson. Vegetation specimens were verified by $P$. Lesica, Faculty Affiliate, Division of Biological Sciences, University of Montana.

\section{Literature Cited}

Aerts, R. 1997. Climate, leaf litter chemistry and leaf litter decomposition in terrestrial ecosystems: a triangular relationship. Oikos 79:439-449.

Aerts, R. 1999. Interspecific competition in natural plant communities: mechanisms, tradeoffs, and plant-soil feedbacks. Journal of Experimental Botany 50:29-37.

Anderson, I. V. 1933. Application of selective logging to a ponderosa pine operation in western Montana. University of Montana Bulletin Number 339. University of Montana, Missoula, Montana, USA.

Arno, S. F. 1980. Forest fire history in the northern Rockies. Journal of Forestry 78:460-465.

Arno, S. F., M. G. Harrington, C. E. Fiedler, and C. E. Carlson. 1995a. Restoring fire-dependent ponderosa pine forests in western Montana. Restoration Management Notes 13:32-36.

Arno, S. F., J. H. Scott, and M. G. Hartwell. 1995b. Age-class structure of old-growth ponderosa pine/Douglas-fir stands and its relationship to fire history. INT-RP-481. USDA Forest Service, Intermountain Research Station, Ogden, Utah, USA. 
$\rightarrow$ Baer, S. G., J. M. Blair, S. L. Collins, and A. K. Knapp. 2004. Plant community response to resource availability and heterogeneity during restoration. Oecologia 139:617-629.

Baruch, Z., and G. Goldstein. 1999. Leaf construction cost, nutrient concentration, and net $\mathrm{CO}_{2}$ assimilation of native and invasive species in Hawaii. Oecologia 121:183-192.

$\rightarrow$ Bonnicksen, T. M., and E. C. Stone. 1982. Reconstruction of a presettlement giant sequioa-mixed conifer forest community using the aggregation approach. Ecology 63:1134-1148.

Brassell, H. M., S. K. Davies, and J. P. Mattay. 1986. Nitrogen fixation associated with bryophytes colonizing burnt sites in southern Tasmania, Australia. Journal of Bryology 13:139149.

Brown, J. K., R. D. Oberheu, and C. M. Johnston. 1982. Handbook for inventorying surface fuels and biomass in the interior west. USDA Forest Service General Technical Report INT-129.

Burnett, M. R., P. V. August, J. H. Brown, and K. T. Killingbeck. 1997. The influence of geomorphological heterogeneity on biodiversity. I. A patch-scale perspective. Conservation Biology 12:363-370.

$\rightarrow$ Burnside, O. C., R. G. Wilson, S. Weisberg, and K. G. Hubbard. 1996. Seed longevity of 41 weed species buried $1^{\prime}$ years in eastern and western Nebraska. Weed Science 44:74 86.

Covington, W. W., and S. S. Sackett. 1984. The effects of a prescribed burn in southwestern ponderosa pine on organic matter and nutrients in woody debris and forest floor. Forest Science 30:183-192.

Covington, W. W., and S. S. Sackett. 1990. Fire effects on ponderosa pine soils and their management implications. USDA Forest Service RM-GTR-191. Rocky Mountain Forest and Range Experiment Station, Flagstaff, Arizona, USA.

Covington, W. W., and S. S. Sackett. 1992. Soil mineral nitrogen changes following prescribed burning in ponderosa pine. Forest Ecology and Management 54:175-191.

DeLuca, T. H., and K. L. Zouhar. 2000. Effects of selection harvest and prescribed fire on the soil nitrogen status of ponderosa pine forests. Forest Ecology and Management 138:263-271.

Dodson, E. K. 2004. Monitoring change in exotic plan abundance after fuel reduction/restoration treatments in ponderosa pine forests of western Montana. Thesis. University of Montana, Missoula, Montana, USA.

Fiedler, C. E. 1995. The basal area-maximum diameter-q $(\mathrm{BDq})$ approach to regulating uneven-aged stands. Miscellaneous Publication Number 56. Montana Forest and Conservation Experiment Station, Missoula, Montana, USA.

Fiedler, C. E. 1999. Stand structure in response to selection cutting and burning. In $\mathrm{H}$. Smith and S. F. Arno, editors. Eighty-eight years of change in a managed ponderosa pine forest. General Technical Report RMRS-23. USDA Forest Service, Rocky Mountain Research Station, Fort Collins, Colorado, USA.

Fiedler, C. E. 2000. Restoration treatments promote growtl and reduce mortality of old-growth ponderosa pine (Montana). Ecological Restoration 18:117-119.

Fiedler, C. E., C. E. Keegan, T. A. Morgan, and C. W. Woodall. 2003. Fire hazard and potential treatment effectiveness: a statewide assessment in Montana. Journal of Forestry 101:7.

Fitter, A. H. 1982. Influence of soil heterogeneity on the coexistence of grassland species. Journal of Ecology 70:139- 148.

Fulé, P. Z., W. W. Covington, and M. M. Moore. 1997. Determining reference conditions for ecosystem management of southwestern ponderosa pine forests. Ecological Applica $\rightarrow$ tions 7:895-908.

$\rightarrow$ Gleason, H. A. 1922. On the relationship between species and area. Ecology 3:158-162.
Grime, J. P. 1973. Competitive exclusion in herbaceous vegetation. Nature 242:344-347.

Gross, K. L., and P. A. Werner. 1982. Colonizing abilities of "biennial" plant species in relation to ground cover: implication for their distributions in a successional sere. Ecology 63:921-931.

Gundale, M. J., T. H. DeLuca, C. E. Fiedler, P. W. Ramsey, M. G. Harrington, and J. E. Gannon. 2005. Restoration management in a Montana ponderosa pine forest: effects on soil physical, chemical, and biological properties. Forest Ecology and Management 213:25-38.

Hardin, G. 1960. The competitive exclusion principle. Science 131:1292-1297.

Hitchcock, C. L., and A. Cronquist. 1973. Flora of the Pacific Northwest. University of Washington Press, Seattle, Washington, USA.

$\rightarrow$ Inouye, R. S., and D. Tilman. 1995. Convergence and divergence of old-field vegetation after $11 \mathrm{yr}$ of nitrogen addition. Ecology 76:1872-1887.

Kaye, J. P., and S. C. Hart. 1998. Ecological restoration alters nitrogen transformations in a ponderosa pine-bunchgrass ecosystem. Ecological Applications 8::1052-1060.

Kruskal, J. B. 1964. Nonmetric multidimensional scaling: a numerical method. Psychometrika 29:115-129.

Lambers, H., and H. Poorter. 1992. Inherent variation in growth rate between higher plants: a search for physiological causes and ecological consequences. Advances in Ecological Research 23:188-261.

$\rightarrow$ MacArthur, R. H., and R. Levins. 1967. The limiting similarity, convergence, and divergence of coexisting species. American Naturalist 101:377-385.

MacArthur, R. H., and E. O. Wilson. 1967. The theory of island biogeography. Princeton University Press, Princeton, New Jersey, USA.

MacKenzie, D. M., T. H. DeLuca, and A. Sala. 2004. Forest structure and organic matter analysis along a fire chronosequence in the low elevation forests of western Montana. Forest Ecology and Management 203:331-343.

Mandzak, J. M., and J. A. Moore. 1994. The role of nutrition in the health of inland western forests. Journal of Sustainable Forestry 2:191-210.

Mast, J. N., P. Z. Fule, M. M. Moore, W. W. Covington, and A. E. M. Waltz. 1999. Restoration of presettlement age structure of an Arizona ponderosa pine forest. Ecological Applications 9:228-239.

Mather, P. M. 1976. Computational methods of multivariate analysis in physical geography. John Wiley and Sons, London, UK

McCune, B., and J. B. Grace. 2002. Analysis of ecological communities. MjM Software Design, Gleneden Beach, Oregon, USA.

Metlen, K. L., and C. E. Fiedler. In press. Restoration treatment effects on the understory of ponderosa pine/ Douglas-fir forests in western Montana, USA. Forest Ecology and Management.

Mittelbach, G. G., C. F. Steiner, S. M. Scheiner, K. L. Gross, H. L. Reynolds, R. B. Waide, M. R. Willig, S. I. Dodson, and L. Gough. 2001. What is the observed relationship between species richness and productivity? Ecology 82:2381-2396.

Monleon, V. J., K. Cromack, and J. D. Landsberg. 1997. Shortand long-term effects of prescribed underburning on nitrogen availability in ponderosa pine stands in central Oregon. Canadian Journal of Forest Research 27:369-378.

Moore, M. M., W. W. Covington, and P. Z. Fulé. 1999. Reference conditions and ecological restoration: a southwestern ponderosa pine perspective. Ecological Applications 9:1266-1277.

Nichols, W. F., K. T. Killingbeck, and P. V. August. 1998. The influence of geomorphological heterogeneity on biodiversity II. A landscape perspective. Conservation Biology 12:371379. 
Nimlos, T. J. 1986. Soils of Lubrecht Experimental Forest. Miscellaneous Publication Number 44. Montana Forest and Conservation Experiment Station, Missoula, Montana, USA.

$\rightarrow$ Petryna, L., M. Mooraj, C. O. Nunes, J. J. Cantero, and M. Zobel. 2002. Are invaders disturbance limited? Conservation of mountain grasslands in central Argentina. Applied Vegetation Science 5:195-202.

$\rightarrow$ Pianka, E. R. 1966. Latitudinal gradients in species diversity: a review of concepts. American Naturalist 100:33-46.

Pollet, J., and P. N. Omi. 2002. Effect of thinning and prescribed burning on crown fire severity in ponderosa pine forests. International Journal of Wildland Fire 11:1-10.

$\rightarrow$ Raison, R. J. 1979. Modification of the soil environment by vegetation fires, with particular reference to nitrogen transformations: a review. Plant and Soil 51:73-108.

$\rightarrow$ Reich, P. B., M. B. Walters, and D. S. Ellsworth. 1997. From tropics to tundra: global convergence in plant functioning. Proceedings of the National Academy of Sciences, USA 94: 13730-13734.

$\rightarrow$ Reynolds, H. L., B. A. Hungate, F. S. Chapin, and C. M. D'Antonio. 1997. Soil heterogeneity and plant competition in an annual grassland. Ecology 78:2076-2090.

Ricklefs, R. E. 1977. Environmental heterogeneity and plan. species diversity. American Naturalist 111::376-381.

$\rightarrow$ Riegel, G. M., R. F. Miller, and W. C. Krueger. 1992 Competition for resources between understory and overstory ponderosa pine. Ecological Applications 2:71-85.

Riegel, G. M., R. F. Miller, and W. C. Krueger. 1995. The effects of aboveground and belowground competition on understory species composition in a Pinus ponderosa forest. Forest Science 41:864-889.

Rozenzweig, M. L., and Z. Abramsky. 1993. How are diversity and productivity related? Pages 52-65 in R. E. Ricklefs and D. Schluter, editors. Species diversity in ecological communities. University of Chicago Press, Chicago, Illinois, USA.

$\rightarrow$ Smith, M. D., and A. K. Knapp. 2001. Physiological and morphological traits of exotic, invasive exotic, and native plant species in tallgrass prairie. International Journal of Plant Science 162:785-792.

Stickney, P. F., and R. B. Campbell. 2000. Database for postfire succession in northern Rocky Mountain forests. USDA Forest Service GTR-RMRS-61CD. Rocky Mountain Research Station, Ogden, Utah, USA.

Sulkava, P., and V. Huhta. 1998. Habitat patchiness affects decomposition and faunal diversity: a microcosm experiment on forest floor. Oecologia 116:390-396.

Tilman, D. 1982. Resource competition and community structure. Princeton University Press, Princeton, New Jersey, USA.

$\rightarrow$ Tilman, D. 1984. Plant dominance along an experimental nutrient gradient. Ecology 65:1445-1453.

Tilman, D., and S. Pacala. 1993. The maintenance of species richness in plant communities. Pages $13-25$ in R. E. Ricklefs and D. Schluter, editors. Species diversity in ecological communities. University of Chicago Press, Chicago, Ilinois, USA.

Vitousek, P. M., and R. W. Howarth. 1991. Nitrogen limitation on land and in the sea: How can it occur? Biogeochemistry 13:87-115.

$\rightarrow$ Vivian-Smith, G. 1997. Microtopographic heterogeneity and floristic diversity in experimental wetland communities. Ecology 85:71-82.

Whittaker, R. H. 1972. Evolution and measurement of species diversity. Taxon 21:213-251.

Willis, R. B., and C. E. Gentry. 1987. Automated method for determining nitrate and nitrite in water and soil extracts. Communications in Soil Science and Plant Analysis 18:625 636.

Willis, R. B., G. J. Schwab, and C. E. Gentry. 1993. Elimination of interferences in the colorimetric analysis of ammonium in water and soil extracts. Communications in Soil Science and Plant Analysis 24:1009-1019.

Zar, J. H. 1999. Biostatistical analysis. Prentice Hall, Upper Saddle River, New Jersey, USA. 